\title{
Business Intelligence Solutions for Wind Power Plants Operation
}

\author{
Simona-Vasilica OPREA, Adela BÂRA \\ Bucharest University of Economic Studies, \\ Department of Economic Informatics and Cybernetics, Bucharest, Romania \\ simona_oprea14@yahoo.com,bara.adela@ie.ase.ro
}

The European Union energy strategies imply significant changes in the power systems. These should contribute to sustainable development and protection of the environment by enabling the EU to achieve its targets set in the third package of legislative proposals for electricity and gas markets. Renewable energy sources (RES) in Romania have been encouraged since 2007 and this lead to a large volume of projects. It took several years to have the first MW installed in wind power plants (WPP). Nowadays, the installed wind power in Romania is about 2642 MW, most of them (about 85\%) being concentrated in the south-eastern part of the country. Based on recorded data during four years in Romania, a couple of analyses have been performed. They contribute to a better integration of wind energy into power systems. This paper will describe how business intelligence solutions are applied on data regarding wind power plants operation and main conclusions that could be drawn.

Keywords: Business Intelligence, Wind Power Plants Operation, Data Integration, Average/Maximum Output

\section{Introduction}

The EU's energy and climate policy objectives consist in completing the internal market in energy, guaranteeing security of supply, notably for gas and oil, reducing greenhouse gas emissions by $20 \%$, increasing the share of renewable energy in the final energy consumption to $20 \%$ and achieving a $20 \%$ increase in energy efficiency by 2020 [1].

Romania as one of the State Members has to fulfil its obligations related to EU's targets in terms of RES integration. The incentive support scheme for RES has been enacted by Law no. 220/2008 for establishing the promoting scheme for energy produced out of RES, Law no. 139/2010 (modifying Law 220/2008) and a series of four governmental orders dated November 2011 [2]. As a result of the supporting scheme mainly based on green certificates, since 2007, a large number of projects have been noticed. Most of them are located in Dobrogea, Moldova and Banat areas as in Figure 1 [3].

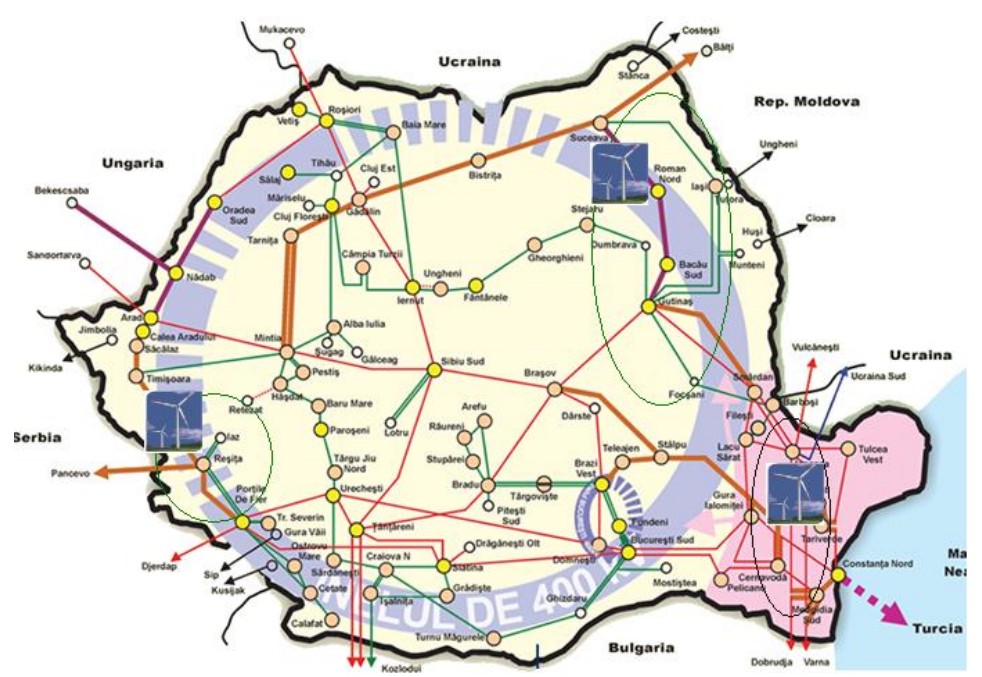

Fig. 1. Areas with large projects in Romania 
This concentration of interest from the pri- tial map as in Figure 2 [4]. vate investors coincides with the wind poten-

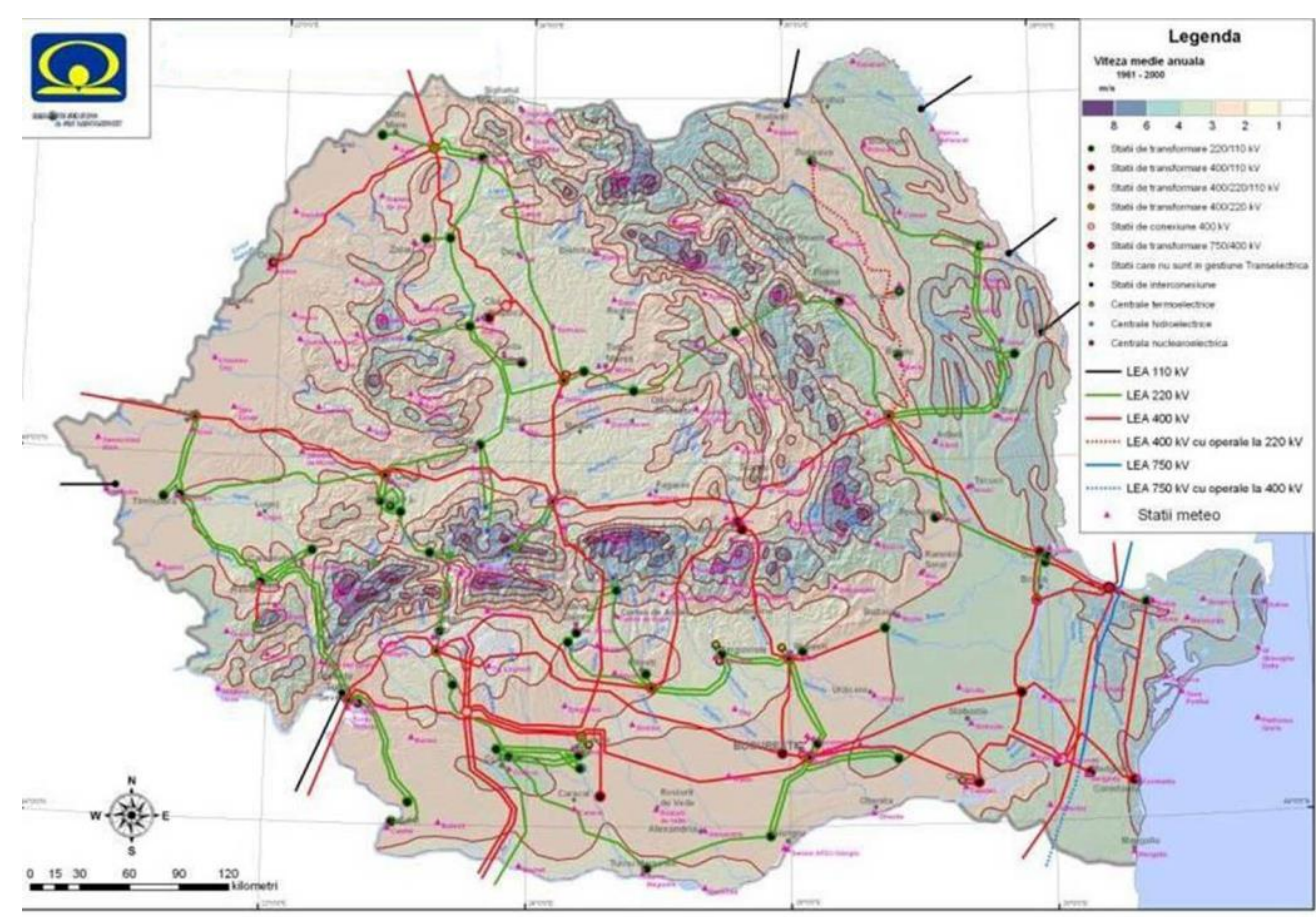

Fig. 2. Wind potential in Romania

Starting from 2010, installed power increased from $13 \mathrm{MW}$ to about $400 \mathrm{MW}$ by the end of the year. In 2011, the installed power was almost double (700 MW) compared with the previous year. The maximum installed power was recorded in 2012 (800 MW), then in 2013 it decreased up to $500 \mathrm{MW}$ and in 2014 as forecast it will decrease even more (270 MW). This evolution is well-related to the specific legislation that incentives RES development. These figures are given in Table 1. Due to the fact that the installing process is very dynamic, the total figures are approximate.

Table 1. Installed power in $2010-2014$

\begin{tabular}{|c|c|c|c|c|c|}
\hline & $M W$ & Winter & Autumn & Summer & Spring \\
\hline $\begin{array}{l}\text { Total } \\
2010\end{array}$ & 400 & $\begin{array}{l}\text { January 2010/ } \\
13 \text { MW }\end{array}$ & $\begin{array}{l}\text { October 2010/ } \\
322 \mathrm{MW}\end{array}$ & - & - \\
\hline $\begin{array}{l}\text { Total } \\
2011\end{array}$ & 700 & $\begin{array}{l}\text { January 2011/ } \\
\text { 424 MW } \\
\text { February 2011/ } \\
\text { 424 MW }\end{array}$ & $\begin{array}{l}\text { November 2011/ } \\
780 \mathrm{MW}\end{array}$ & $\begin{array}{l}\text { June 2011/ } \\
518 \text { MW } \\
\text { August 2011/ } \\
563 \mathrm{MW} \\
\end{array}$ & $\begin{array}{l}\text { March 2011/ } \\
518 \mathrm{MW}\end{array}$ \\
\hline $\begin{array}{l}\text { Total } \\
2012\end{array}$ & 800 & $\begin{array}{l}\text { December 2012/ } \\
\text { 1941 MW } \\
\text { January 2012/ } \\
1140 \text { MW }\end{array}$ & - & $\begin{array}{l}\text { June 2012/ } \\
1314 \text { MW }\end{array}$ & - \\
\hline $\begin{array}{l}\text { Total } \\
2013\end{array}$ & 500 & $\begin{array}{l}\text { December 2013/ } \\
2507 \mathrm{MW}\end{array}$ & $\begin{array}{l}\text { October 2013/ } \\
2325 \mathrm{MW}\end{array}$ & $\begin{array}{l}\text { July 2013/ } \\
2123 \mathrm{MW}\end{array}$ & $\begin{array}{l}\text { April 2013/ } \\
2095 \text { MW }\end{array}$ \\
\hline $\begin{array}{l}\text { Total } \\
2014\end{array}$ & $\begin{array}{l}270 \\
\text { (forecast) }\end{array}$ & - & - & $\begin{array}{l}\text { July 2014/ } \\
2642 \text { MW }\end{array}$ & - \\
\hline
\end{tabular}

Figure 3 shows the WPP installed power evo- lution from 2010 until 2014. 


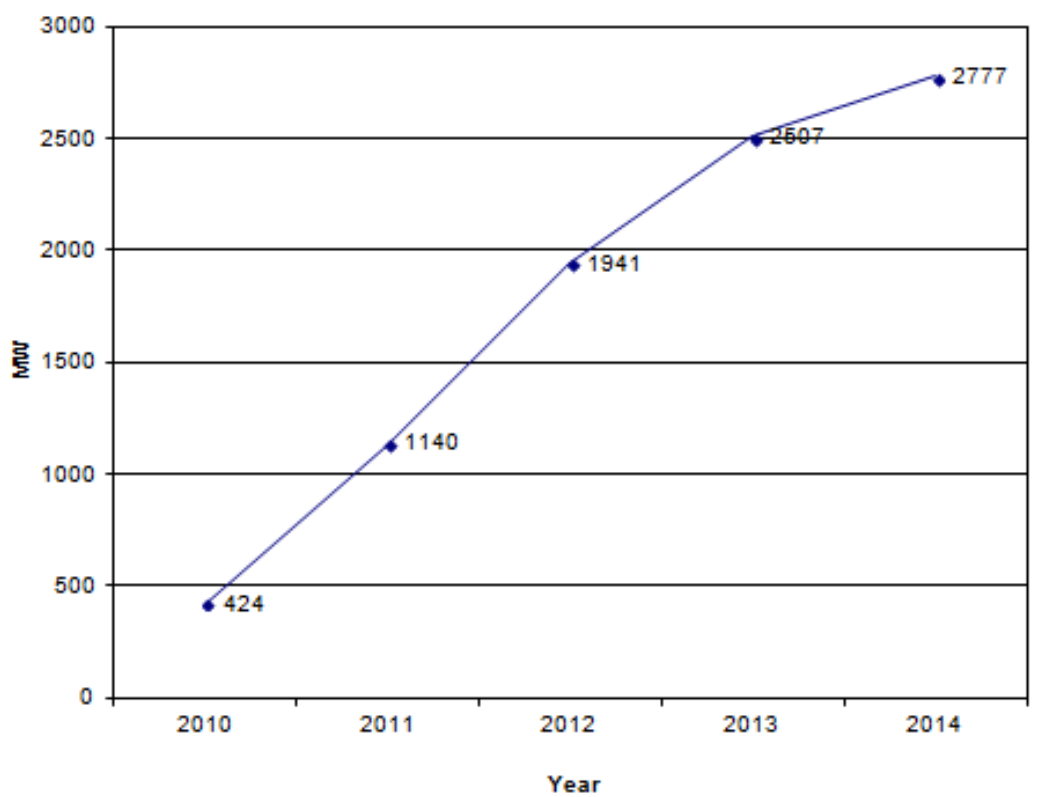

Fig. 3. Installed power evolution from 2010 up to 2014

Its trend is ascending, but in the last two years, it has been moderated by legislative means. For 2014 the increase for the first half of the year was double so that to get an approximate value for entire year.

\section{Data Integration and Analysis Models}

In the research project [5] we aim to develop a set of templates for data integration in a central database within the online platform, to define a set of performance indicators at macro level and to develop analytical and interactive reports for monitoring these indicators intended for supporting decisions. We'll propose simulation models of the operation of power plants at regional and national level, models that are based on data mining techniques and developed with geospatial elements for tracking indicators through interactive maps. A particularly important indicator on which to base an accurate forecast of the produced energy from renewable sources is the degree of simultaneity of operation of wind power plants located in different geographical areas. Wind energy production is conditioned by several factors factors such as: slipstream effect, soil orography, power characteristics, losses up to the connection point of etc. These factors are identified and detailed in the fundamental works [6], [7]. The analytical component developed for national authorities will contain a model for determining the degree of simultaneity which will allow a more accurate dimensioning of power reserves in the system. Thus, if some of the production companies in a given area will have an accurate prediction system, based on the degree of simultaneity of the model we will be able to determine and correct the estimation of production for those power plants without efficient prediction systems (for e.g. undispatchable units or units that have systems with big errors) as described in [8].

The proposed model will have advanced data analysis capabilities and it can be used to improve decision-making and ensure knowledge management. The component for national operators will allow the streamlining of the information flow, required statements and reports being obtained automatically via the online platform.

The prototype's interfaces will be developed so as to allow users single access to the system via mobile devices, and the use of the Cloud Computing platform will allow the connecting of servers, services and applications necessary for the prototype, thus 
streamlining access to information to decision makers and reducing infrastructure costs. The system will enable effective and real-time analysis of the operation of renewable power plants. Also, using an integrated platform, through which there are monitored and analyzed in real time all the renewable power plants included in the system provides a competitive advantage when integrating with similar networks in the European Union. The first phase of the project involves identifying and analyzing the data sources, by designing the conceptual database diagrams and mappings between data. The conceptual data model will be designed. The system must implement the features of an integrated decision support system, using multidimensional models through which we can implement technological and business workflows. We will define the Business Intelligence methods and technologies used for analysis and data presentation and we'll define the main components of the system based on the following levels: the data level, the model analysis level and the presentation level. But first of all, an analyses of the WPP operation over time is needed, based on the data series recorded in the last 4 years.

\section{Business intelligence analyses of WPP operation}

Taking into account the large available recorded data set that describes the global operation of WPP between 2010 and 2013 (over 200000 records), business intelligence solutions will be used. No business intelligence technique has been applied for wind power plants operation until now. Out of data set some interesting results are found such as hourly average WPP output grouped by studied years, comparison among curves that describe hourly average WPP output, relation between WPP output and installed power in WPP in terms of maximum and average values and seasonal analyses on each studied year.

Figure 4 depicts average WPP output hour by hour in January. The first three studied years WPP output was almost flat, but in 2013 lower values were recorded around 5 and 12 o'clock and higher values were recorded at 21. Some similarities are identified between 2012 and 2013 curves up to 12 o'clock.

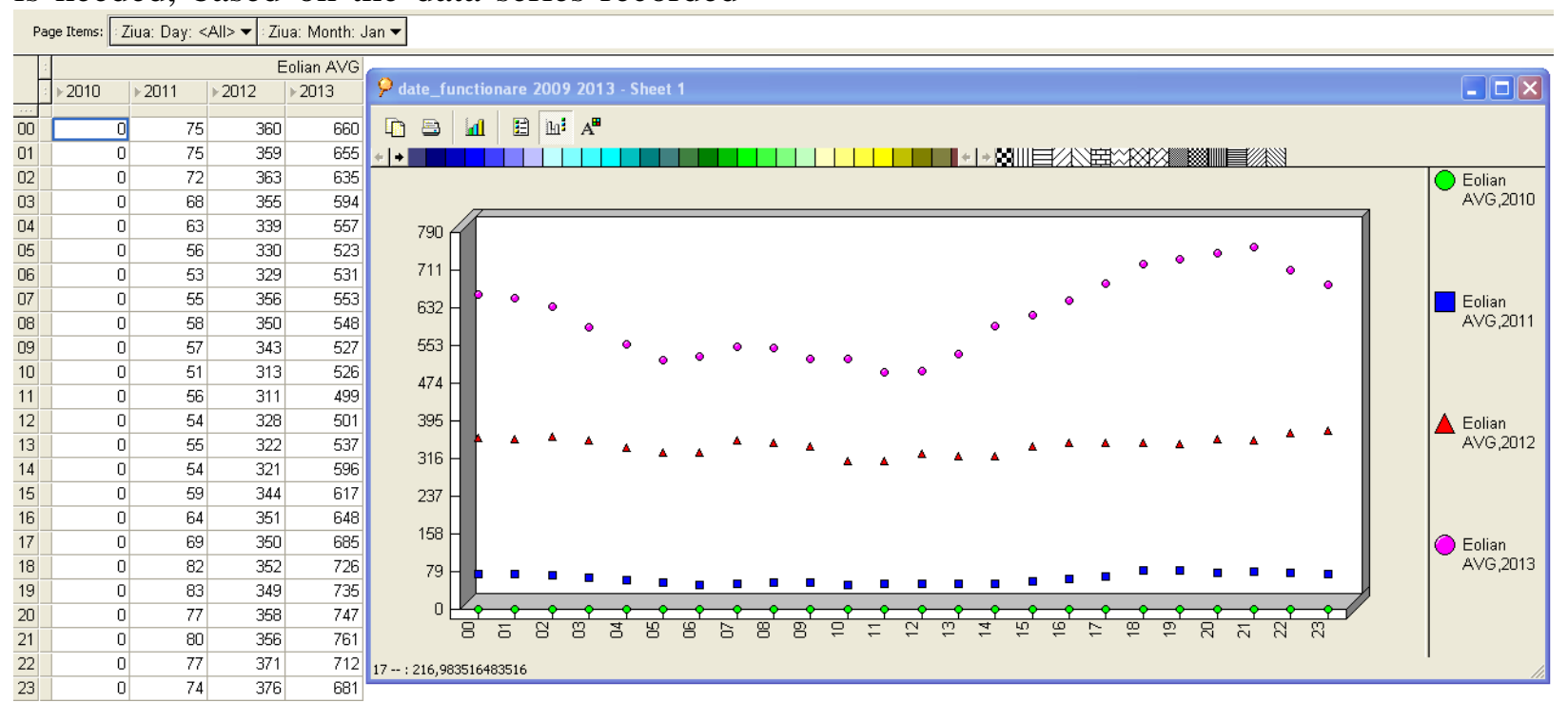

Fig. 4. Hourly average WPP output in January 2010-2013

Table 2 shows average and maximum values for WPP output in January in 2011 and 2012. It shows the difference between two consecu- tive years. Average output in 2012 is double compared with 2011. 
Table 2. Average and maximum values in January 2011 and 2012

\begin{tabular}{|r|r|r|l|}
\hline 2011 JAN & 2011 JAN & 2012 JAN & 2012 JAN \\
\hline \%AVG(Pi) & \%MAX(Pi) & \%AVG(Pi) & \%MAX(Pi) \\
\hline 15 & 82 & 30 & 73 \\
\hline
\end{tabular}

Figure 5 depicts average WPP output hour by years (2011 and 2012) WPP output is quite hour in February. The middle two studied similar.

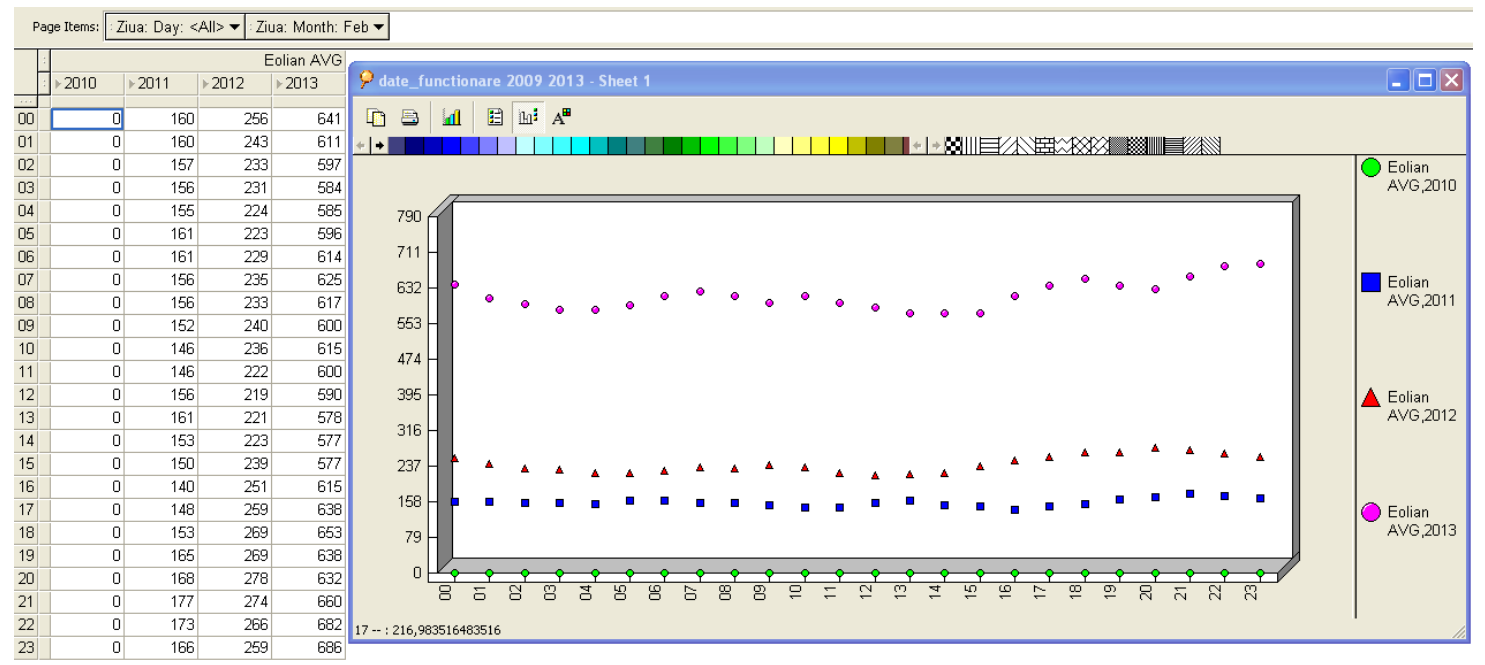

Fig. 5. Hourly average WPP output in February 2010-2013

Figure 6 depicts average WPP output hour by hour in March. The last two studied years (2012 and 2013) WPP output was similar be- tween 6 and 15 o'clock. The rest of time intervals trends are different. As for WPP output in 2011 is quite flat.

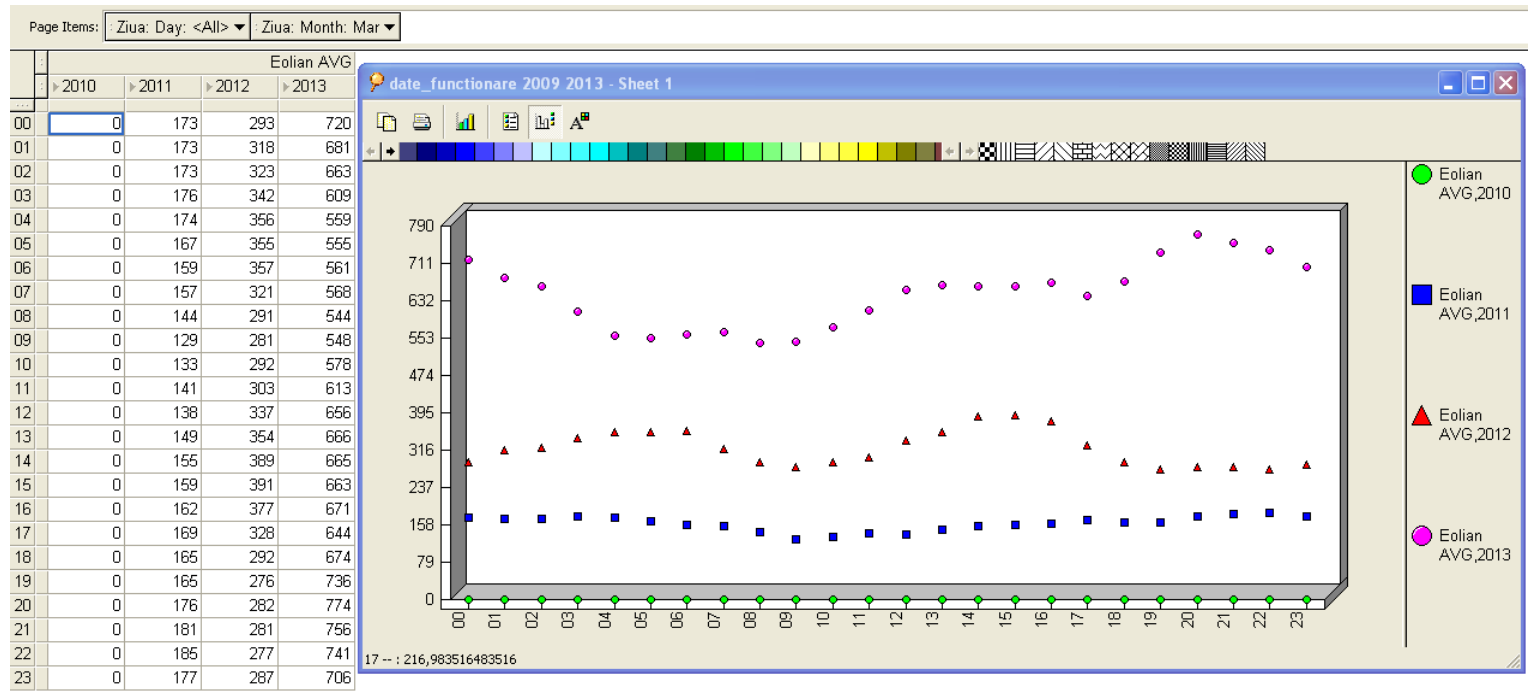

Fig. 6. Hourly average WPP output in March 2010-2013

Table 3 shows average and maximum values recorded in March. The maximum value shows that for short time intervals WPP output was almost equal to installed power.

Table 3. Average and maximum values in

\begin{tabular}{|} 
March 2011 \\
\begin{tabular}{|r|r|}
\hline 2011 MAR & 2011 MAR \\
\hline \%AVG(Pi) & \%MAX(Pi) \\
\hline 31 & 98 \\
\hline
\end{tabular}
\end{tabular}

Figure 7 depicts average WPP output hour by 
hour in April. WPP output in 2011 and 2013 was slightly similar. WPP output in 2013 has many windings. WPP output in 2011 and 2012 are quite different, but with little wind- ings. As for WPP output in 2010 is quite flat up to June-July when significant power was installed.

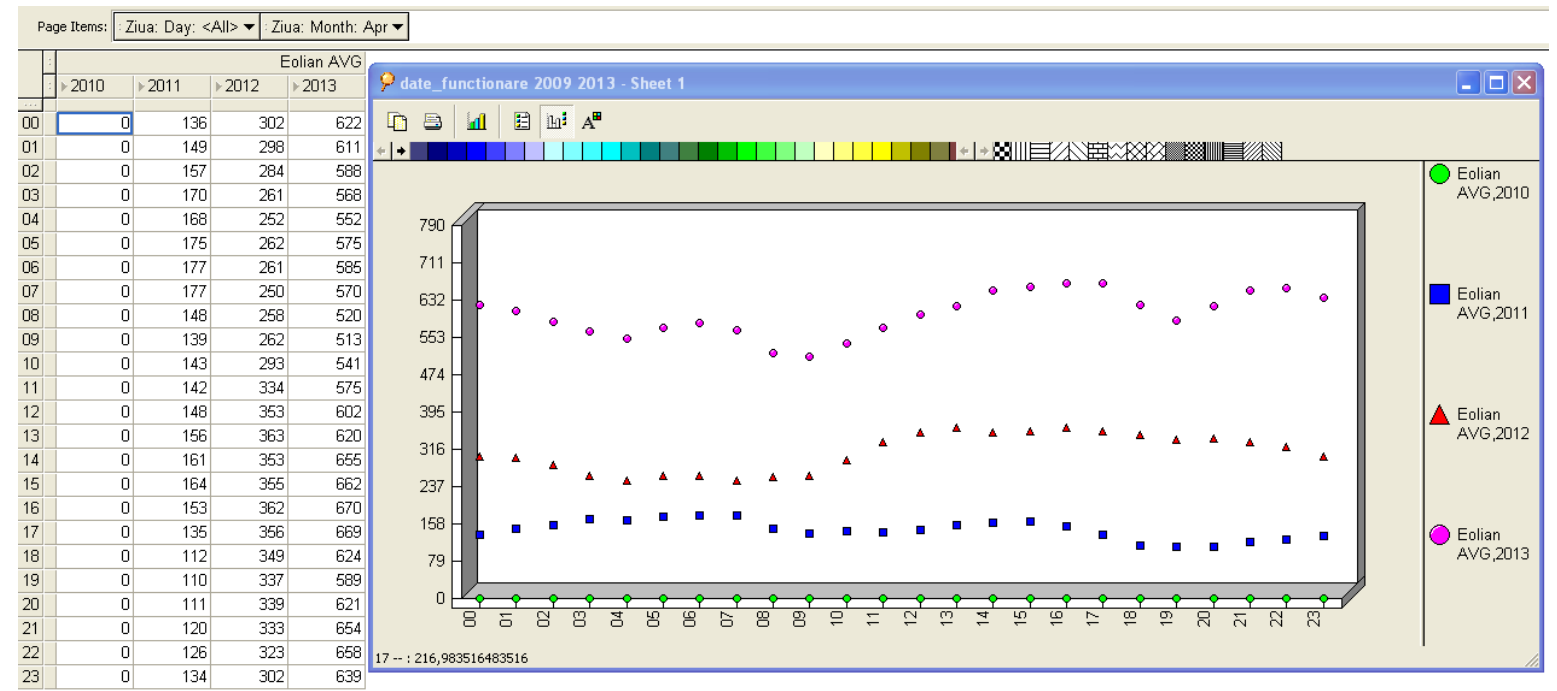

Fig. 7. Hourly average WPP output in April 2010-2013

Table 4 shows average and maximum values recorded in April.

Table 4. Average and maximum values in

\begin{tabular}{|c|c|}
\multicolumn{2}{c}{ April 2011} \\
\hline 2013 APR & 2013 APR \\
\hline \%AVG(Pi) & \%MAX(Pi) \\
\hline 29 & 88 \\
\hline
\end{tabular}

These values are significant because in 2013 the installed power increased over $2000 \mathrm{MW}$. Average values of WPP output is about $30 \%$ and maximum value is almost $88 \%$ of installed power.

Figure 8 depicts average WPP output hour by hour in May. WPP output in 2013 is opposite with load curve and it does not help balance of the power system. WPP output in 2011 and 2012 are similar, but with little windings.

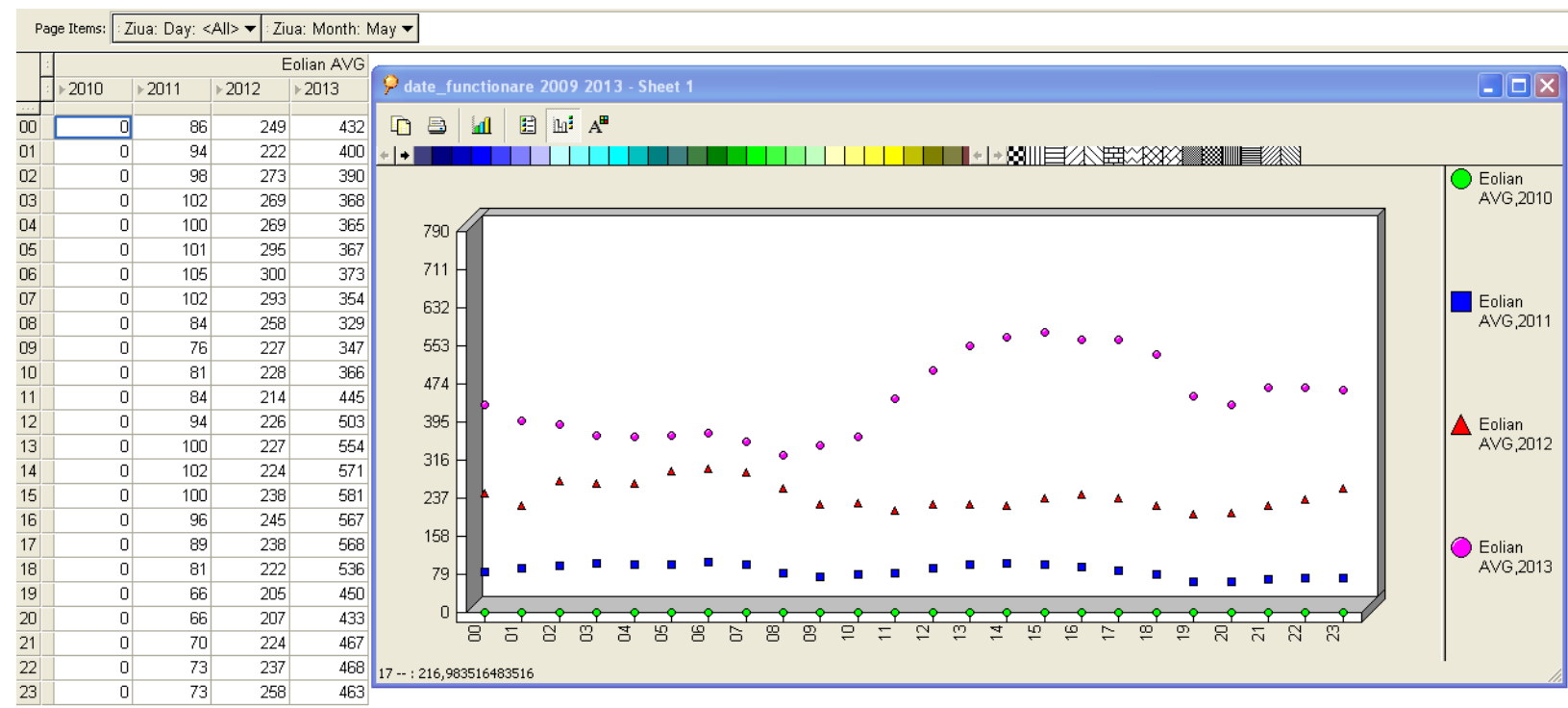

Fig. 8. Hourly average WPP output in May 2010-2013 
Figure 9 depicts average WPP output hour by hour in June. All three important curves are similar and again they are opposite with load curve and do not help balance of the power system. This month the level of output is much smaller than in winter and spring time.

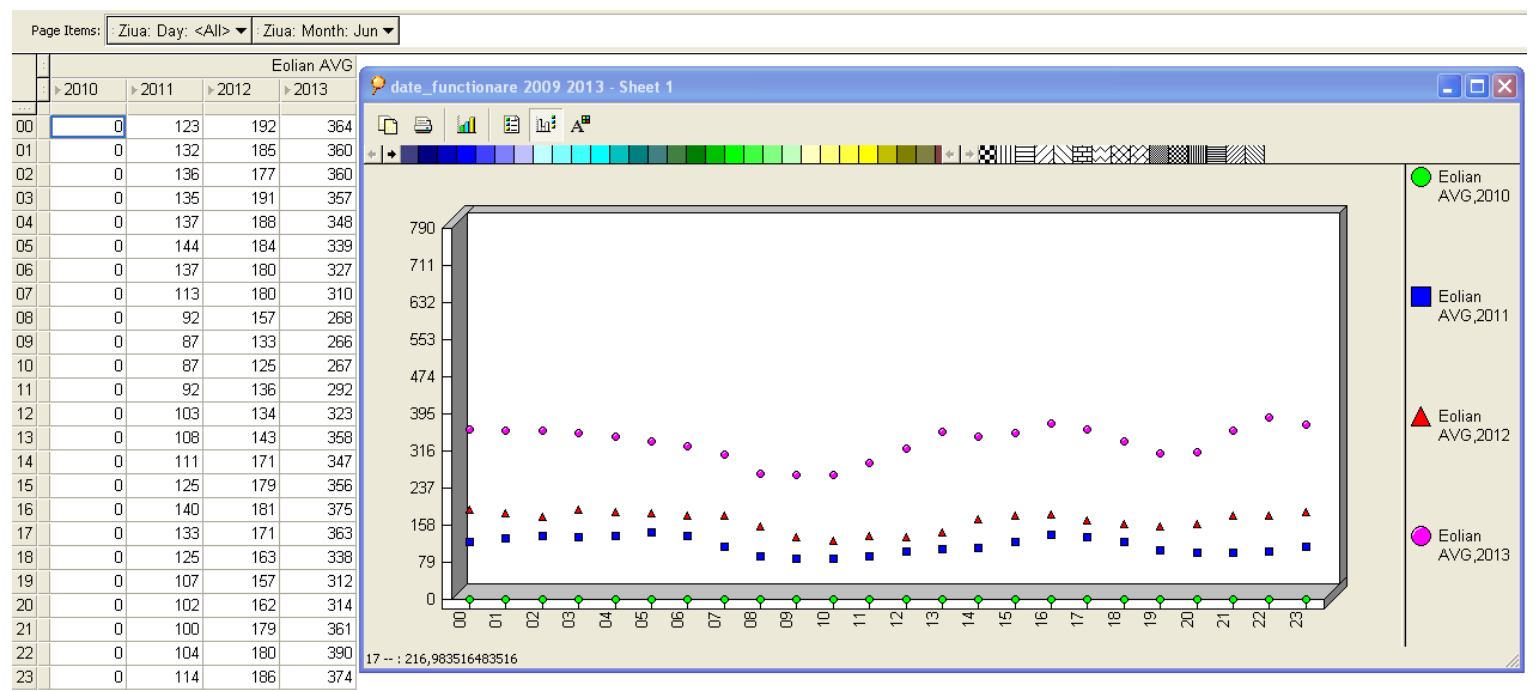

Fig. 9. Hourly average WPP output in June 2010-2013

Table 5 shows average and maximum values recorded in June.

Table 5. Average and maximum values in

\begin{tabular}{|r|r|}
\hline \multicolumn{2}{|c|}{ June 2012} \\
\hline 2012 IUN & 2012 IUN \\
\hline \%AVG(Pi) & $\% \mathrm{MAX}(\mathrm{Pi})$ \\
\hline 13 & 65 \\
\hline
\end{tabular}

Average value of WPP output is about $13 \%$ and maximum value is almost $65 \%$ of installed power.

Figure 10 depicts average WPP output hour by hour in July. All three important curves are similar and again they are opposite with load curve and do not help balance of the power system. This month the level of output is much smaller than in winter and spring time. WPP output in July is similar with WPP output in June.

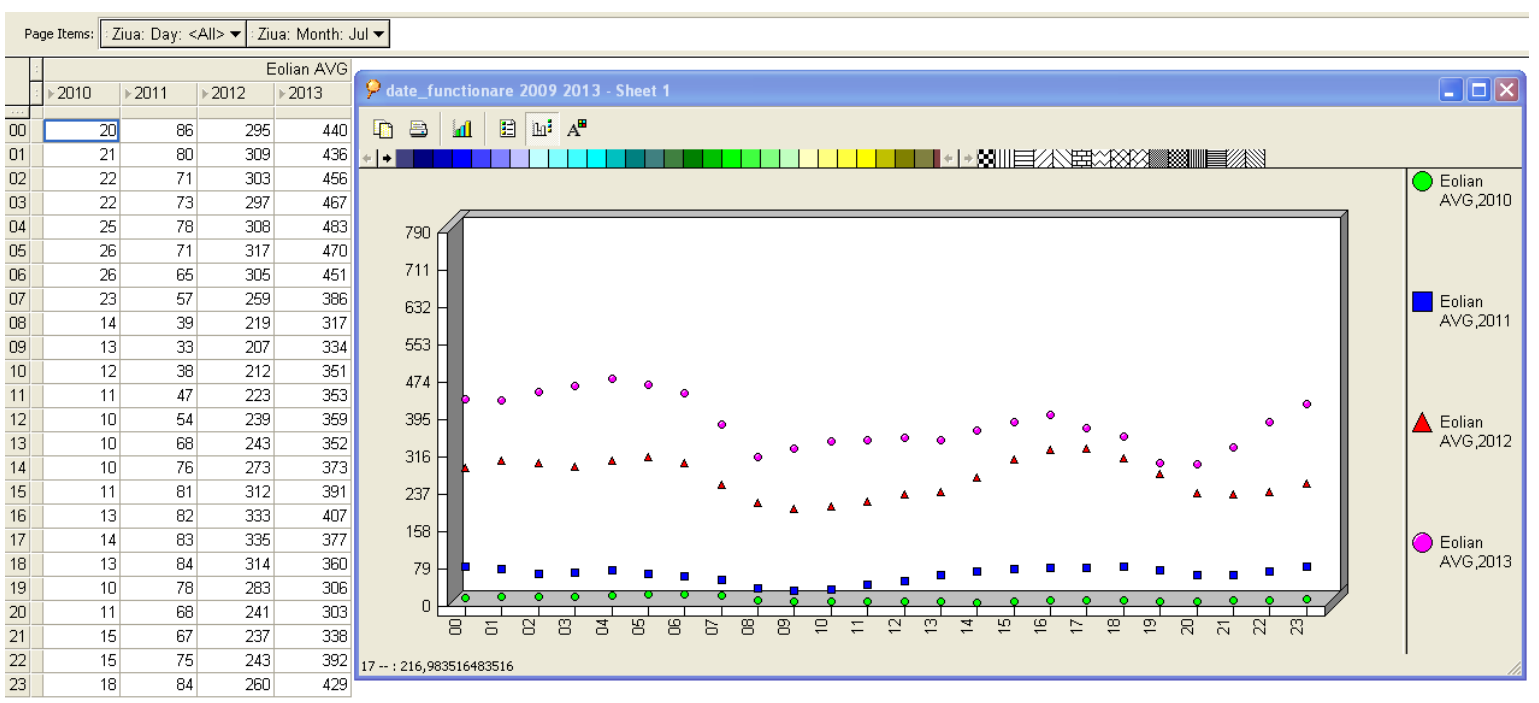

Fig. 10. Hourly average WPP output in July 2010-2013

Table 6 indicates average and maximum percentage of installed power recorded in July 2013.
Figure 11 depicts average WPP output hour by hour in August. 
Table 6. Average and maximum values in July 2013

\begin{tabular}{|l|l|}
\hline $2013 \mathrm{IUL}$ & $2013 \mathrm{IUL}$ \\
\hline$\% \mathrm{AVG}(\mathrm{Pi})$ & $\% \mathrm{MAX}(\mathrm{Pi})$ \\
\hline
\end{tabular}

18

WPP output in 2012 and 2013 are similar. WPP output in summer is similar.

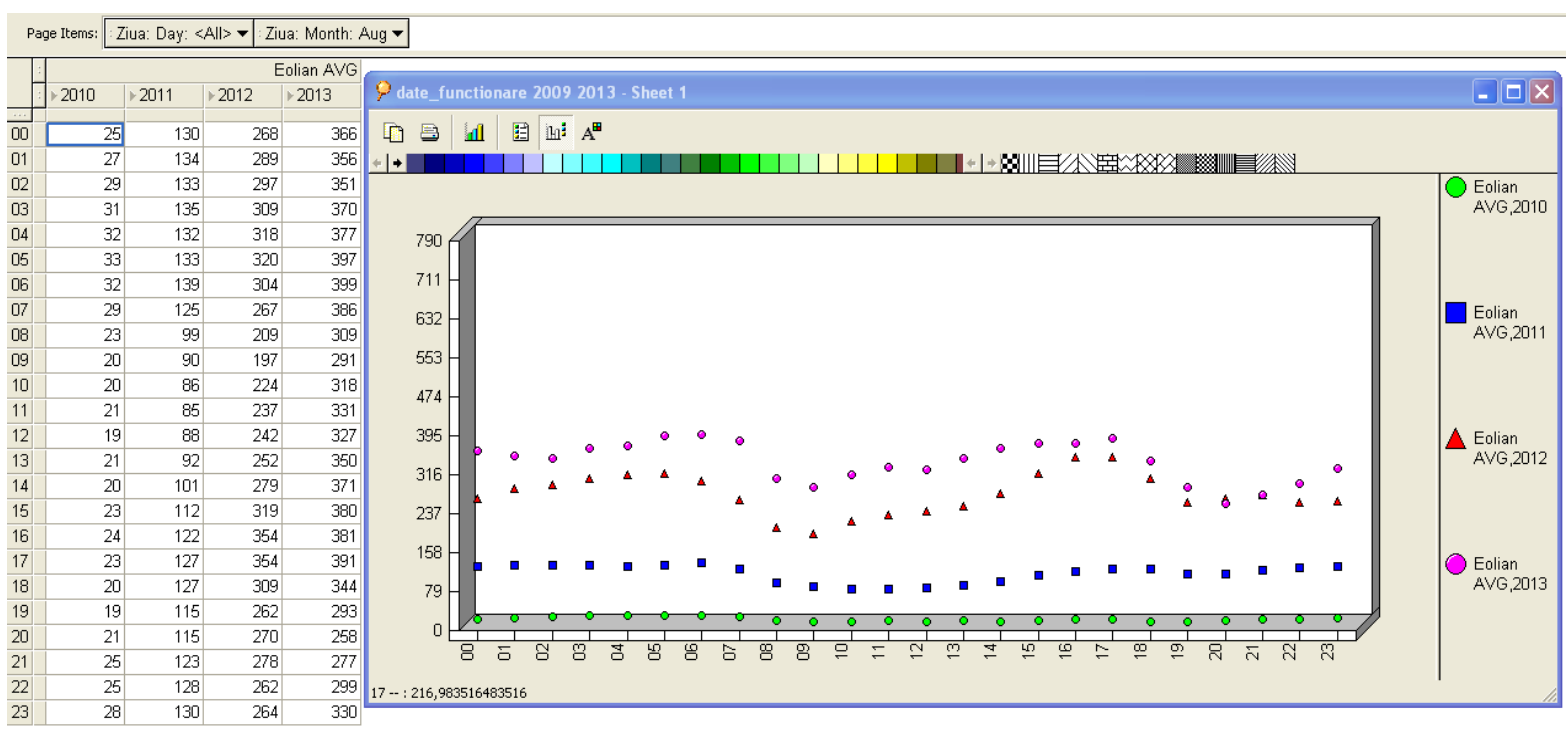

Fig. 11. Hourly average WPP output in August 2010-2013

Table 7 indicates average and maximum percentage of installed power recorded in August 2011.

Figure 12 depicts average WPP output hour by hour in September. This month the level of WPP output is increasing.
Table 7. Average and maximum values in August 2011

\begin{tabular}{|r|r|}
\hline 2011 AUG & 2011 AUG \\
\hline \%AVG(Pi) & \%MAX(Pi) \\
\hline 21 & 94 \\
\hline
\end{tabular}

In 2011 and 2012 the curves are similar, but different from 2013 curve.

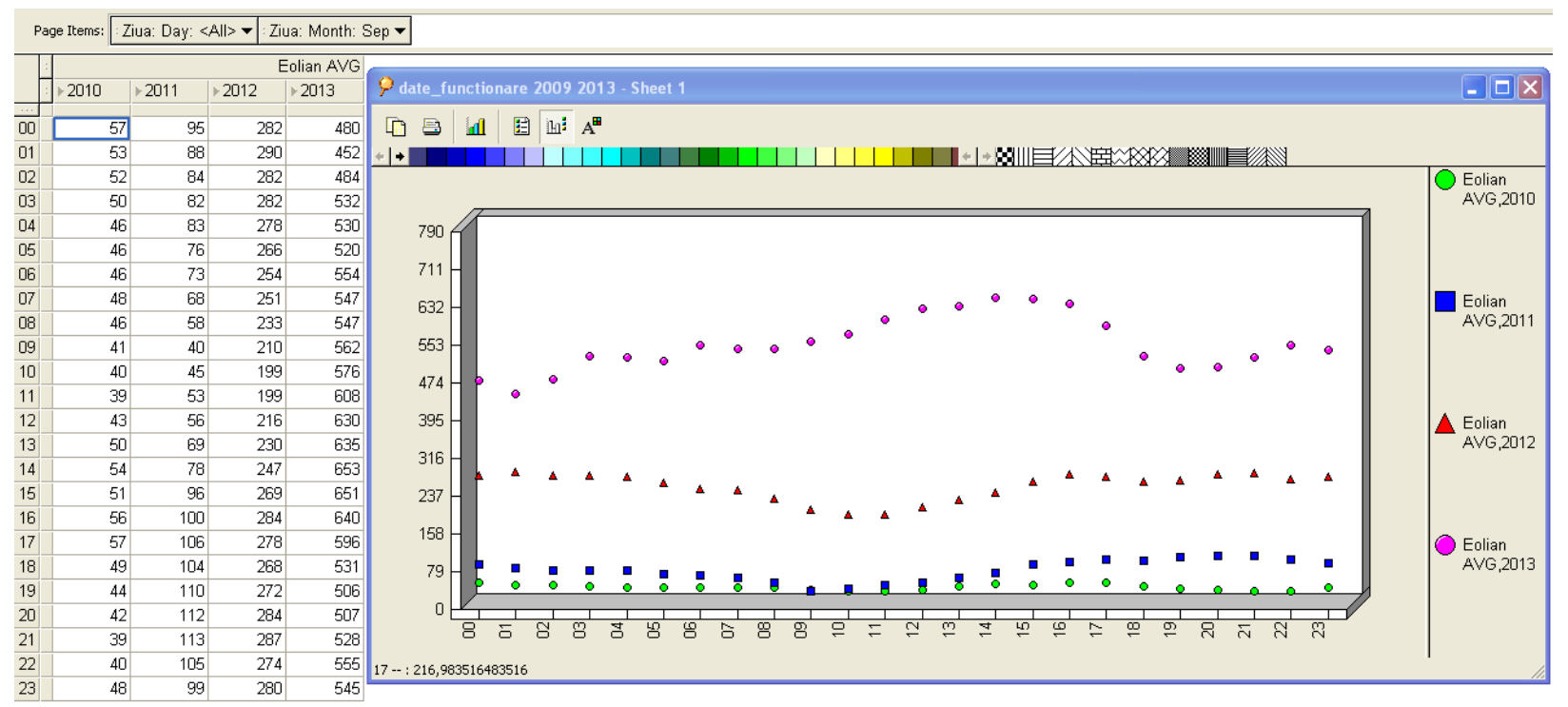

Fig. 12. Hourly average WPP output in September 2010-2013

Figure 13 depicts average WPP output hour by hour in October. This month the level of 
WPP output is higher than WPP output of the are similar and flat. In 2012 and 2013 the previous month. In 2010 and 2011 the curves curves are very similar.

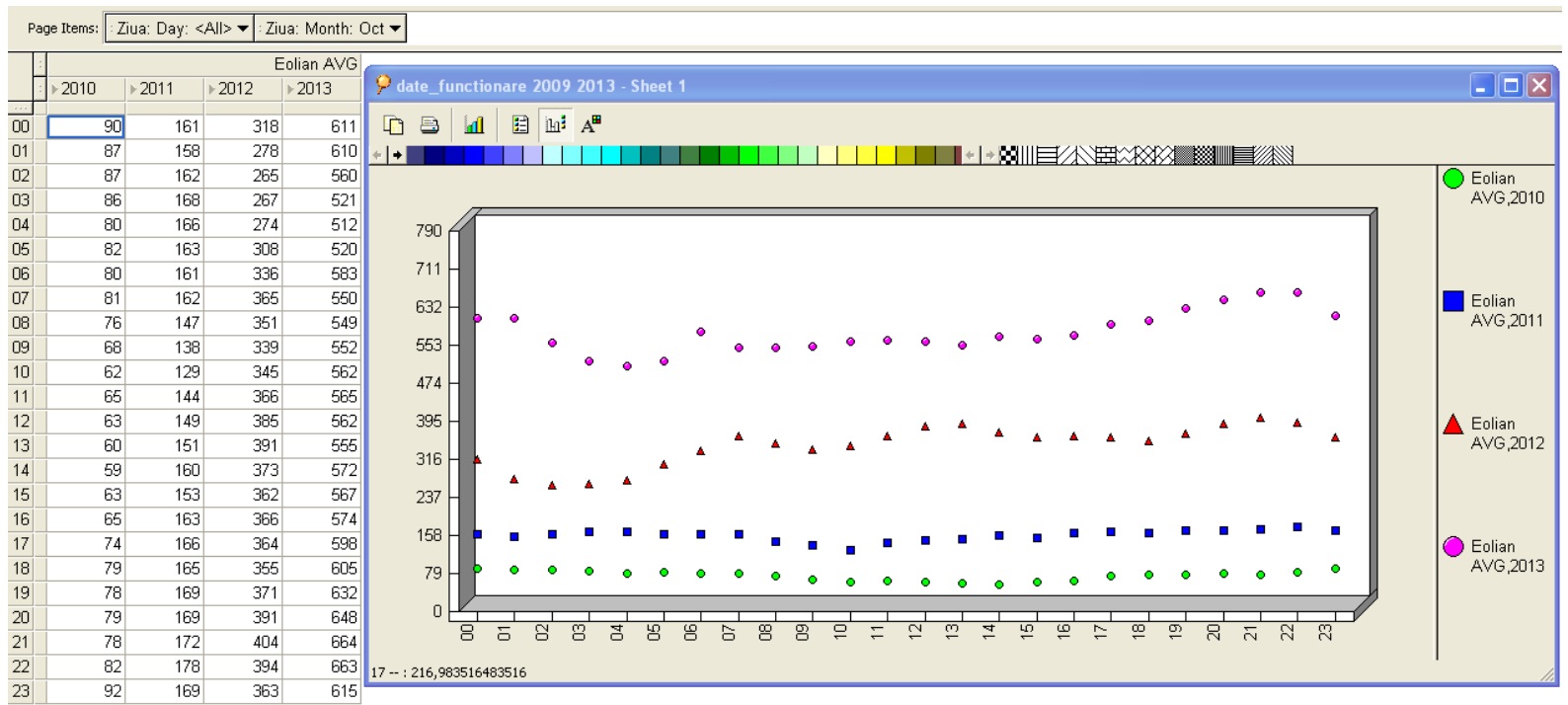

Fig. 13. Hourly average WPP output in October 2010-2013

Table 8 indicates average and maximum per- ber 2010 and 2013. centage of installed power recorded in Octo-

Table 8. Average and maximum values in October 2010 and 2013

\begin{tabular}{|r|r|r|r|}
\hline 2010 OCT & 2010 OCT & 2013 OCT & 2013 OCT \\
\hline \%AVG(Pi) & \%MAX(Pi) & \%AVG(Pi) & \% MAX(Pi) \\
\hline 23 & 77 & 25 & 85 \\
\hline
\end{tabular}

Figure 14 depicts average WPP output hour of the previous months. In 2010 and 2011 the by hour in November. This month the level curves are similar and flat. In 2012 and 2013 of WPP output is the higher than WPP output the curves are very similar.

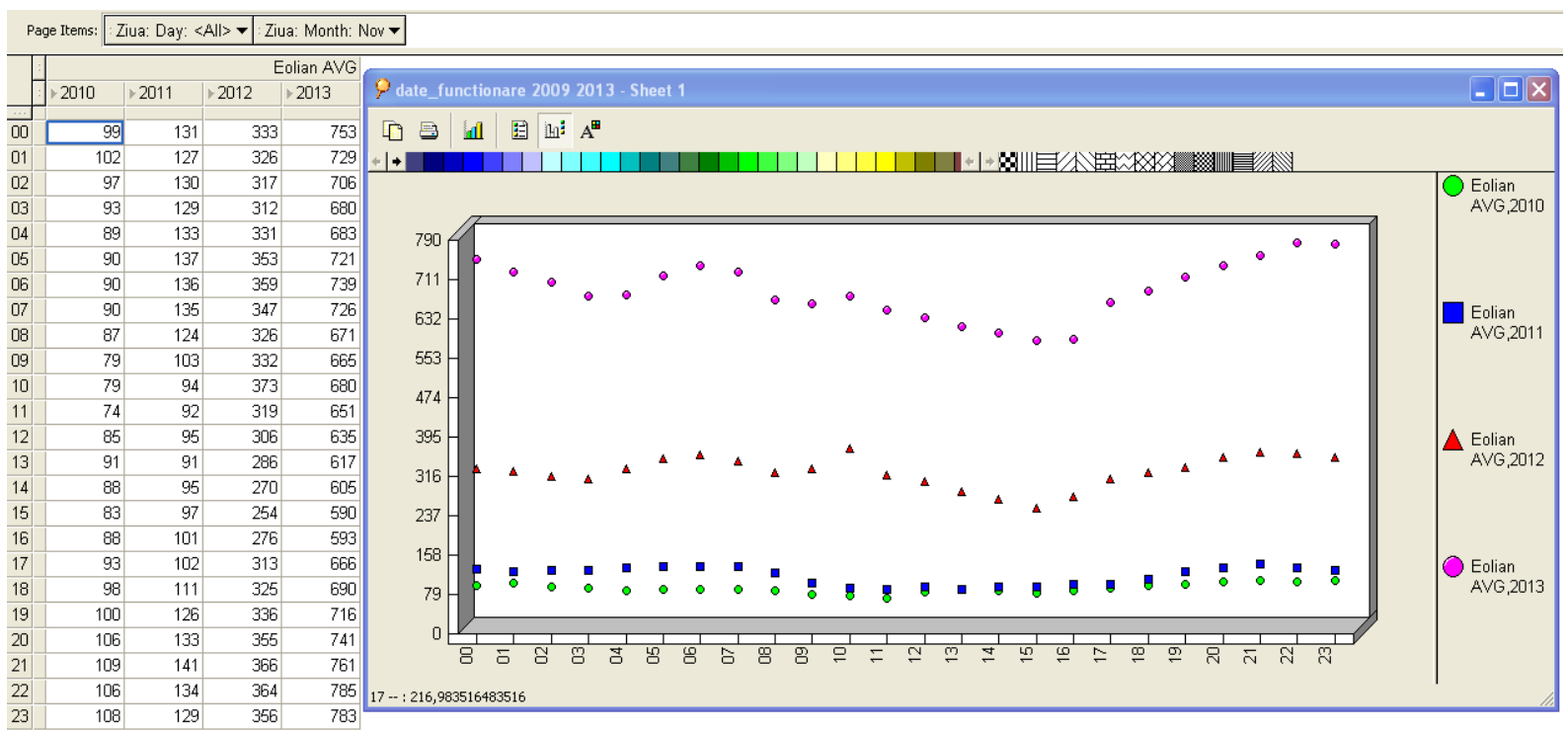

Fig. 14. Hourly average WPP output in November 2010-2013

Table 9 indicates average and maximum per- centage of installed power recorded in Octo- 
ber 2010 and 2013.

Table 9. Average and maximum values in November 2010 and 2013

\begin{tabular}{|r|r|}
\hline $2011 \mathrm{NOV}$ & $2011 \mathrm{NOV}$ \\
\hline$\%$ AVG(Pi) & $\% \mathrm{MAX}(\mathrm{Pi})$ \\
\hline 15 & 72 \\
\hline
\end{tabular}

Figure 15 depicts average WPP output hour by hour in December. This month the level of WPP output is much higher than WPP output of the previous months. In 2010 and 2011 the curves are similar and flat. In 2012 WPP output is almost flat, but in 2013 the curve has more windings.

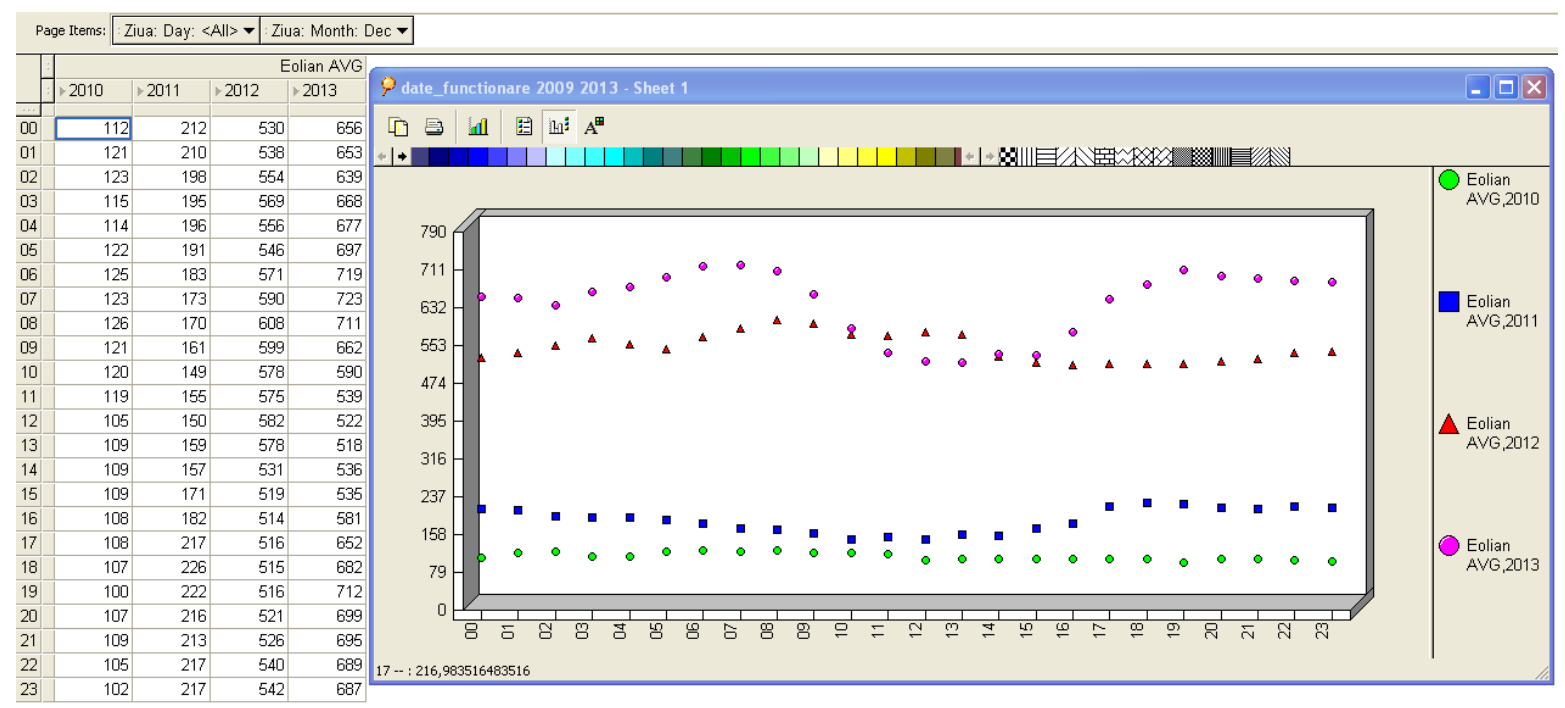

Fig. 15. Hourly average WPP output in December 2010-2013

Table 10 indicates average and maximum December 2012 and 2013. percentage of installed power recorded in

Table 10. Average and maximum values in December 2012 and 2013

\begin{tabular}{|r|r|r|r|}
\hline 2012 DEC & 2012 DEC & 2013 DEC & 2013 DEC \\
\hline \%AVG(Pi) & \%MAX(Pi) & \%AVG(Pi) & \%MAX(Pi) \\
\hline 28 & 81 & 26 & 91 \\
\hline
\end{tabular}

Maximum values recorded in December reveals that even if they are taken from two consecutive years, differences can be significant. Figure 16 depicts average WPP output hour by hour each month in 2013. At the beginning of the year about $2000 \mathrm{MW}$ have been installed. By the end of the year about
$2500 \mathrm{MW}$ have been installed. In this figure WPP monthly output is compared. In winter time the level of WPP output is much higher (more than double) than WPP output in summer time. The lowest level is about 240 MW and the highest level is about $790 \mathrm{MW}$. 


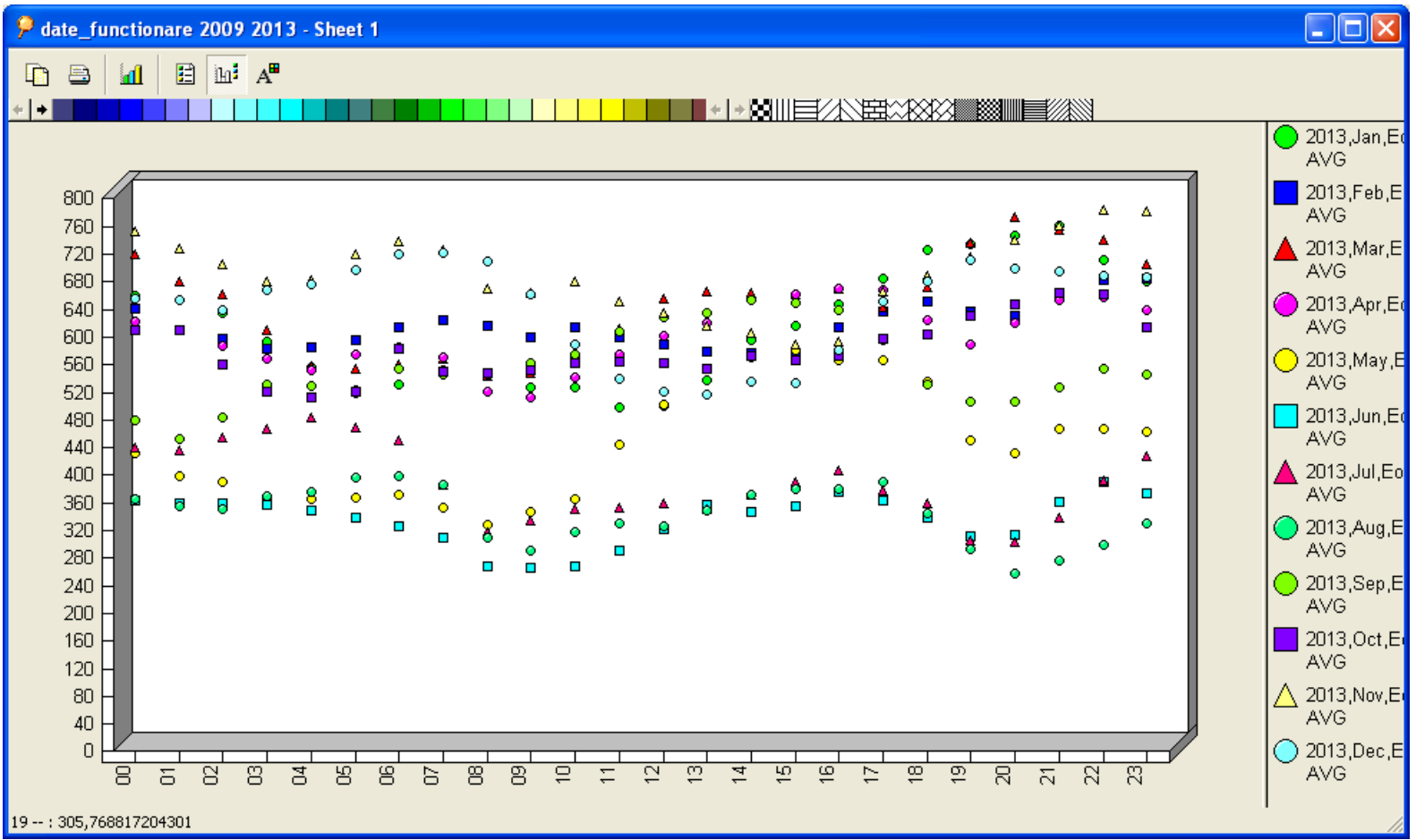

Fig. 16. Hourly average WPP output each month in 2013

Figure 17 depicts average WPP output hour by hour each month in 2012. At the beginning of the year about $1100 \mathrm{MW}$ have been installed. By the end of the year about 1900 MW have been installed. In this figure WPP monthly output is compared. In winter time the level of WPP output is much higher than WPP output in summer time. The lowest level is about $120 \mathrm{MW}$ recorded in June and the highest level is about $600 \mathrm{MW}$ recorded in December. As for the rest of the months, the curves are quite close and compact.

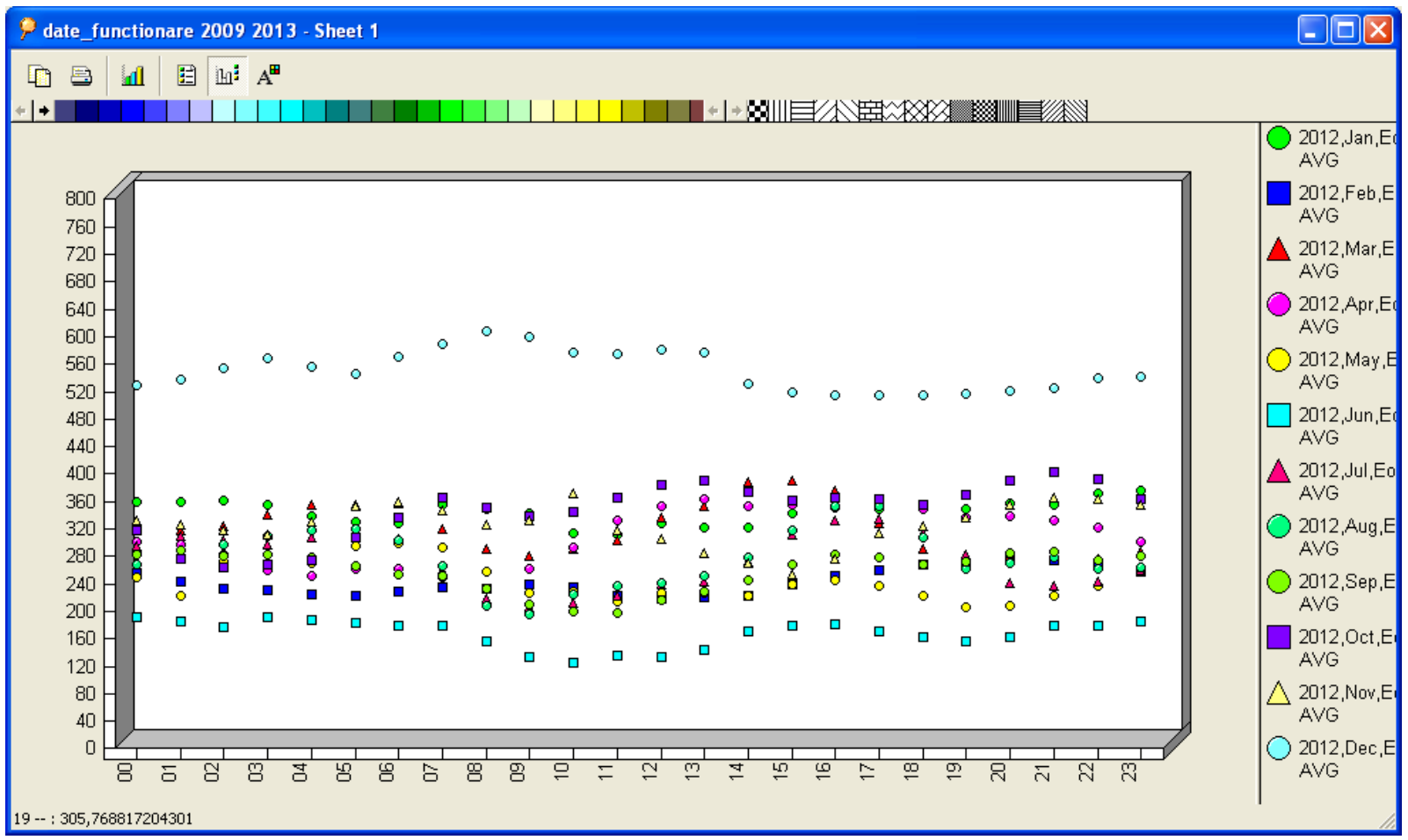

Fig. 17. Hourly average WPP output each month in 2012 
Figure 18 shows the same average WPP out- smaller scale. put hour by hour each month in 2012 at

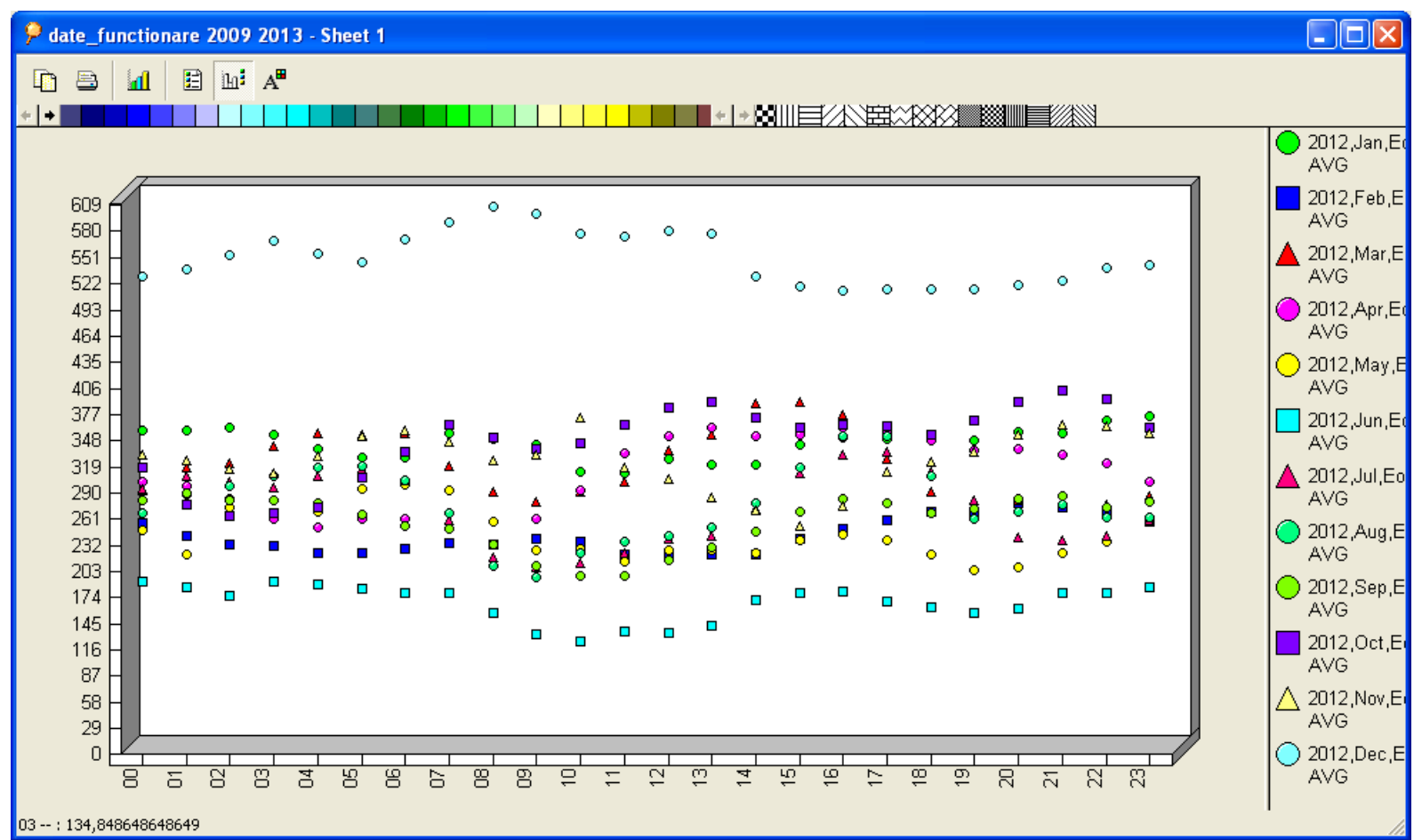

Fig. 18. Hourly average WPP output each month in 2012

Figure 19 depicts average WPP output hour stalled. By the end of the year about 1100 by hour each month in 2011. At the begin- MW have been installed. In this figure WPP ning of the year about $400 \mathrm{MW}$ have been in- monthly output is compared.

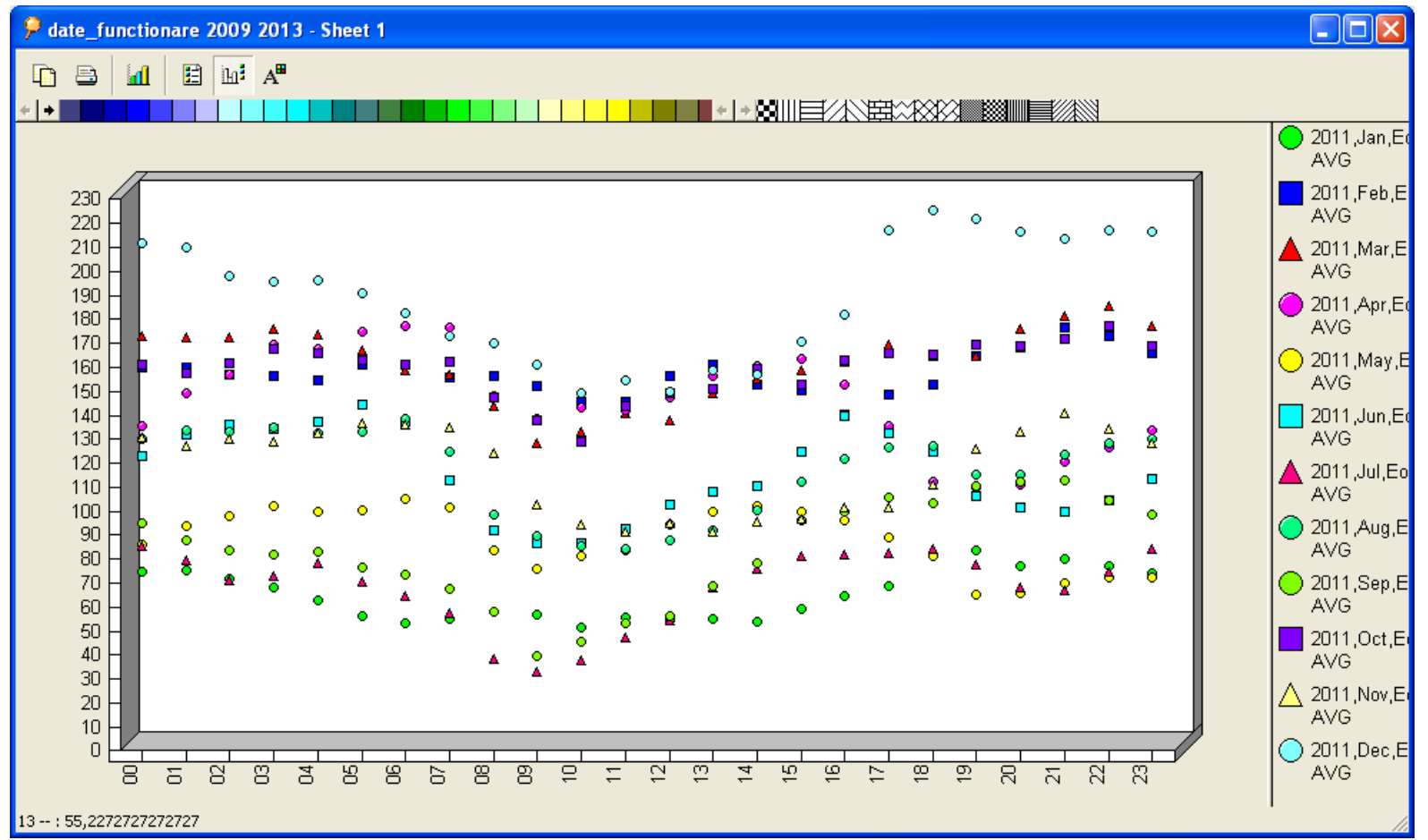

Fig. 19. Hourly average WPP output each month in 2011 
In winter time the level of WPP output is higher than WPP output in summer time. The lowest level is about 30 MW recorded in July and the highest level is about $220 \mathrm{MW}$ recorded in December [9].

\section{Conclusions}

Starting from 2010, installed power increased from $13 \mathrm{MW}$ to about $400 \mathrm{MW}$ by the end of the year. In 2011, the installed power was almost double (700 MW) compared with the previous year. The maximum installed power was recorded in 2012 (800 MW), then in 2013 it decreased up to $500 \mathrm{MW}$ and in 2014 as forecast it will decrease even more (270 MW). This evolution is well-related to the specific legislation that incentives RES development.

Taking into account the large available recorded data set that describes the global operation of WPP between 2010 and 2013 (over 200000 records), business intelligence solutions developed by Oracle will be used. No business intelligence technique has been applied for wind power plants operation until now. Out of data set some interesting results are found such as hourly average WPP output grouped by studied years, comparison among curves that describe hourly average WPP output, relation between WPP output and installed power in WPP in terms of maximum and average values and seasonal analyses on each studied year.

The main conclusions regarding WPP operation in Romania are:

- wind blows more at night that is not helpful for system operation;

- summer months were less windy;

- if we compare WPP output in the same month in two consecutive years, the difference could be significant;

- average WPP output could be considered no more than $30 \%$ and maximum WPP output could be considered around $80 \%$.

Although in this paper several analysis regarding WPP operation are presented for different consecutive years, it is obvious that more data is required in order to obtain better correlations and more significant conclusion that could be useful in power systems opera- tion.

\section{Acknowledgement}

This paper presents some results of the research project: A. Bara (coord) - Sistem inteligent pentru predicția, analiza și monitorizarea indicatorilor de performanță a proceselor tehnologice şi de afaceri în domeniul energiilor regenerabile (SIPAMER), research project, PNII - Parteneriate în domeniile prioritare, PCCA 2013, code 0996, 2014

\section{References}

[1] Parlamenul European, "Directiva 72/2009/CE a Parlamentului European si a Consiliului privind normele comune pentru piaţa internă a energiei electrice și de abrogare a Directivei 54/2003/CE", 2009

[2] S. Oprea, D. Petrescu, D. Bolborici, O. Stănescu, "Aspects related to te wind power plants operation in Romania", CIE 2012 Oradea

[3] S. Oprea, "Aspecte privind accesul deschis la reţelele electrice - Integrarea surselor regenerabile de energie", $\mathrm{PhD}$ thesis, Bucureşti, 2009

[4] ANM, Administraţia Naţională de Meteorologie - online reports available at http://www.meteoromania.ro/anm/?page_ id $=138$

[5] A. Bara (coord), "Sistem inteligent pentru predicția, analiza și monitorizarea indicatorilor de performanță a proceselor tehnologice și de afaceri în domeniul energiilor regenerabile", (SIPAMER), research project, PNII - Parteneriate în domeniile prioritare, PCCA 2013, code 0996, 2014

[6] L. Landberg, G. Giebel, H.A. Nielsen, T.S. Nielsen, H. Madsen, "Short-term prediction - An overview", Wind Energy 6(3), 2003, pp.273-280;

[7] T. Ackerman, "Wind Power", John Wiley \& Sons, 2005, 742 pp;

[8] A. Bara, A. Velicanu, I. Lungu, I. Botha, "Natural Factors that Can Affect Wind Parks and Possible Implementation Solutions in a Geographic Information System", Proc. of the International Confer- 
ence on Development, Energy, Environment, Economics, 2010, pp.50-54, ISBN 978-960-474-253-0
[9] Transelectrica SA, online reports available:http://www.transelectrica.ro/4Operare SEN/functionare.php

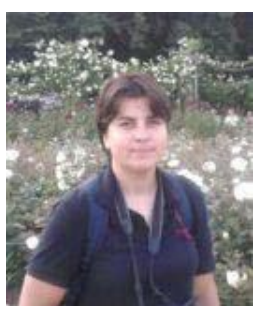

Simona Vasilica OPREA is a Senior Engineer and she has graduated the Polytechnic University in 2001, holds a Master Diploma in Infrastructure Management Program, Yokohama National University, Japan in 2007 and a $\mathrm{PhD}$ diploma from 2009. She is the author of over 20 articles, from which 3 ISI Web of Science indexed and 2 included in SCOPUS international database. Domains of competence: wind farm, investment opportunity analysis, studies of prognosis, stationary and dynamic regimes, short circuit calculations. Since 2014 she is PhD candidate at the Bucharest University of Economic Studies.

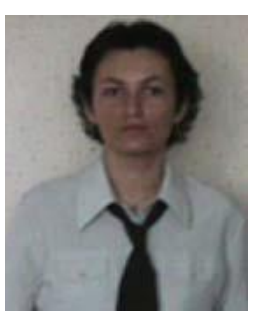

Adela BÂRA is Associate Professor at the Economic Informatics Department at the Faculty of Cybernetics, Statistics and Economic Informatics from the Academy of Economic Studies of Bucharest. She has graduated the Faculty of Economic Cybernetics in 2002, holds a PhD diploma in Economics from 2007. She is the author of 7 books in the domain of economic informatics, over 40 published scientific papers and articles (among which over 20 articles are indexed in international databases, ISI proceedings, SCOPUS and 10 of them are ISI indexed). She participated as team member in 3 research projects and has gained as project manager two research contract, financed from national research programs. She is a member of INFOREC professional association. From May 2009, she is the director of the Oracle Excellence Centre in the university, responsible for the implementation of the Oracle Academy Initiative program. Domains of competence: Database systems, Data warehouses, OLAP and Business Intelligence, Executive Information Systems, Decision Support Systems, Data Mining. 